Available online at GSC Online Press Directory

GSC Biological and Pharmaceutical Sciences

e-ISSN: 2581-3250, CODEN (USA): GBPSC2

Journal homepage: https://www.gsconlinepress.com/journals/gscbps

(RESEARCH ARTICLE)

\title{
Evaluation of phytochemicals and activity index of some plant leaf extracts on typhoidal and non-typhoidal Salmonella isolates from selected hospitals in Bauchi, Nigeria
}

\author{
Naphtali Esther, Tahir Fatima * and Agbo Ediga B * \\ Department of Microbiology, Abubakar Tafawa Balewa University, Bauchi, Nigeria.
}

Publication history: Received on 28 October 2019; revised on 14 February 2020; accepted on 17 February 2020

Article DOI: https://doi.org/10.30574/gscbps.2020.10.2.0204

\begin{abstract}
The pytochemicals and activity index evaluation was done for antibacterial activity of aqueous and methanol extracts of Cymbopogan citratus, Psidium guajava and Anacadium occidentale on clinical isolates of typhoidal and non typhoidal Salmonella. The typhoidal Salmonella isolates where $S$. typhi and S. paratyphi A, while non typhoidal was $S$. typhimurium. Well diffusion method was used. The activity of extracts was compared with that of orthodox drugs commonly used for the treatment of typhoid and non-typhoid salmonellosis thus; ciprofloxacin (10 $\mu$ g/Disc),

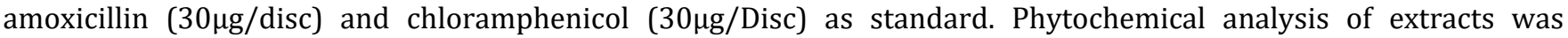
conducted using Trease and Evans methods of 2002. Both methanol and aqueous extracts had significant $(\mathrm{p}<0.05)$ in vitro activity Comparison of extract with antibiotics show activity index (AI) as follows: Chloramphenicol have AI $\leq 1$ on the salmonella serotypes of both solvent extracts implying that Chloramphenicol is still of use. Amoxacilin have $\mathrm{AI}>1$ on the serotypes indicating that Amoxacilin is resistant to salmonella serotypes tested. Using Ciprofloxacin as a standard, AI varies with serotypes $S$. paratypi $A$ and $S$. typimurium have AI $\leq 1$ and $S$. typi have AI $>1$.Pyhtochemical screening of extract revealed the presence of some bioactive components like alkaloids saponin, tannins, anthraquinones steroid flavonoids glycosides. These properties determined the antimicrobial potential of the extracts. From the findings, it proved that plants crude extracts possess some potential as antibiotics and can be further studied to isolate the compound that is most active and formulated as drug against the disease.
\end{abstract}

Keywords: Phytochemicals; Activity Idex (AI); Typhoida; antibiotics.

\section{Introduction}

Salmonelosis is a disease caused by salmonella species which are members of the family enterobacteriaceace. They are gram negative facultative anaerobic rods. Salmonella species are classified into serovars (serotypes) based on the lipopolysacharide (O) flagellar protein $(\mathrm{H})$ and sometimes the capsular (VI) antigens. There are more than 2500 known serovars, within a serovar, there may be strains that differ in virulence [9] Salmonella is generally divided into two categories; non typhoidal and typhoidal. The non typhoidal salmonella is the most common form and is carried by both humans and animals. Most serotypes of salmonella such as Salmonella jariana and Salmanolla entiritidis cause non typhoidal salmonellosis. Salmonella typhimurium is involving in the invasive non typoidal. [9].

The serovars responsible for typhoid fever is restricted to human beings, which is transmitted through direct contact with the feacal matter of an infected person, that is to say it's transmitted through feaco-oral route. Typhoid fever is endemic in developing and under developed world where unsanitary conditions are more likely to prevail and which

\footnotetext{
${ }^{*}$ Corresponding author

E-mail address: fatimatahir3@gmail.com; ediga_agbo@yahoo.com
} 
can affect as many as 21.5 million people, each year. Recorded cases of typhoid fever in the developed world are mostly related to recent travel to areas where, salmonella Typhoid is endemic.

Typhoid fever symptoms appear between 8 - 14days after eating contaminated food and last anywhere from 3 to 60days. They include fever, weakness, lethargy abdominal pain, coughing, nose bleeding and delirium and enlarged organs. Typhoid fever is a serious illness that can result in death [4].

Herbal medicine is still the main stay of about $75-80 \%$ of the world population, particularly, in developing countries for primary health care [8]. This is primarily because of the general belief that herbal drugs are without any side effects. Besides, they are cheap and locally available. Before scientists made impact into the research for drugs curing human infections, the traditional means of treating diseases were done by means of concoctions from plants either in single form or mixtures without knowing that the agents were used against some pathogenic micro-organism [17]. Limited knowledge about the practices of use of plant medication that is herbal medicine and lack of scientific studies of plants have led to the neglect of novel bioactive components that may bring about remarkable result in treatment of infectious diseases with little or no side effect [15].

Medicinal plants are known to contain in one or more of its organ substances that can be used for therapeutic purpose or as precursors for synthesis of useful drugs [17]. Many of such plants known to be used primitively to alleviate symptoms of illness have been screened to have medicinal importance, some of which include Azadirachta indica (Dogonyaro), Zingiber officinale (Ginger), Piper guineese (Iyere) Allium stativiam (Garlic), Vernomia amydalina (Bitter leaf). These plants have been reportedly used in the traditional treatment of ailments such as stomach disorder, fever symptoms and cough [10].

Besides this efficacy, plants have little or no side effects in treatment of diseases because they act as food and as medicines. In the treatment of hypertension for instance herbs are used first to lower the blood pressure to clean the arteries, to slow and regulate the heart beat rate, to improve the circulation of blood and relax the mind, un like the fundamental conventional drugs that will dilate the arteries or the veins until they reach maximum elastic point which may suddenly burst and cause vascular accident, causing stroke or death [11]. Typhoidal salmonella which is the most resistant to antibiotics of the serovars, hence, finding the right antibiotic for it is a crucial matter; as a result, alternative means must be employed to find solutions to this problem such as use of herbs. This actually predates the introduction of antibiotics and modern drugs in Africa. The existence of human beings without the availability of plants would have been made very difficult. Different plants produce different compounds which vary in their antimicrobial action and organisms differ in their sensitivity to these compounds.

In the last three decades, the search for natural bioactive compounds that can serve as antimicrobial agents had increased tremendously due to the increasing resistance possessed by microorganisms to synthetic antibiotic [12].

The scope of this study includes isolation of Salmonella, extraction of African lemon grass (Cymbopogan Citratus) guava leaf (Psidium guajava) cashew leaf (anacardium Occidentale) and the testing of the efficacy of these extract on the isolate.

\section{Material and methods}

\subsection{Ethical Clearance}

The consent of the clinically suspected patients was sort, while the Ethics Committee of Abubakar Tafawa Balewa University teaching Hospital Bauchi gave approval for the study. Confidentiality of the subjects' identities was duly maintained.

\subsection{Study Area}

The study area is Bauchi Local Government Area, where samples were collect from new General Hospital Bayara, Specialist Hospital and ATBU Teaching Hospital, Bauchi state is located on Lat. $10.6371^{\circ} \mathrm{N}$, long. $10.0807 \stackrel{\circ}{\mathrm{E}}$ the vegetation is that of savanna and sahel according to Koppen's climat classification system. Bauchi LGA is located on Lat. $10.301^{\circ} \mathrm{N}$ long. $9.8237^{\circ} \mathrm{E}$, it's area is $3,687 \mathrm{~km} 2$ and has population of 493,810 according to 2006 population census. 

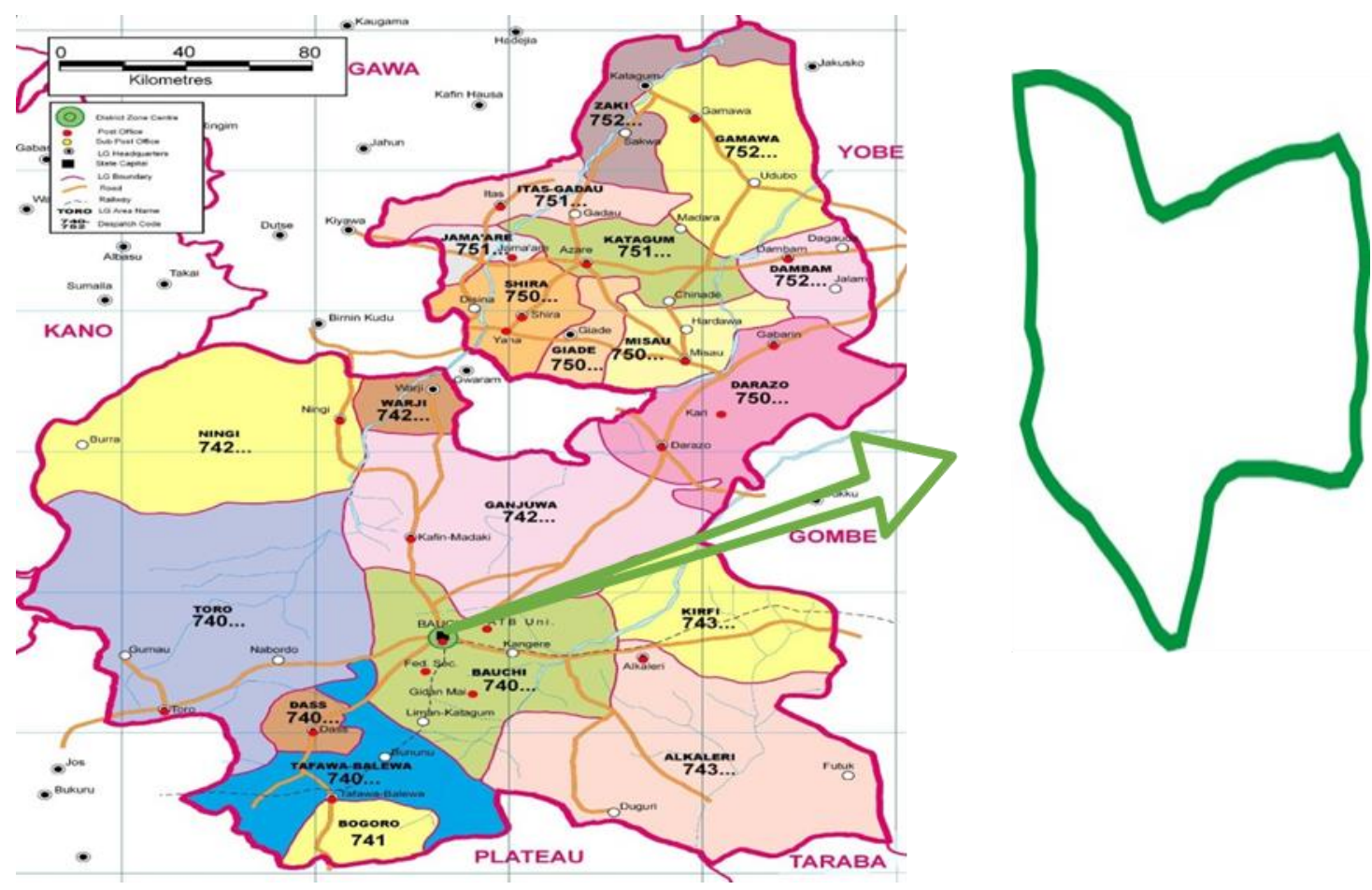

Figure 1 Map of Bauchi State Indicating Bauchi LGA

\subsection{Sample collection}

\subsubsection{Clinical samples}

A total of 210 clinical samples were collected, blood and stool Samples were collected from patient with febrile or diarrheal illness attending new General Hospital Bayara, Specialist Hospital and ATBU Teaching Hospital, Bauchi on weekly basis from May to August 2016. Blood sample were collected using syringe and needle while stool samples were collected using sterile bottles, patient where served with sterile bottles to collect a small quantity of their stools.

\subsubsection{Plants collection and identification}

Plant samples collected or used are African lemon grass (Cymbopogan citratus), Cashew leaf (Anacardium Occidentale) and guava leaf (Psidium guajava). These were collected at Mbak area of Dass town a local government in Bauchi state where they are found to be growing naturally or planted delibrately and transported to ATBU herbarium for authentication with the following voucher numbers; Psidium guajava ATBUHB 2489, Anacardium Occidentale ATBUHB 2490 and Cymbopogan citrates ATBUHB 2491.

\subsection{Isolation, Characterization and Identification of Typhoidal and Non-Typhoidal Salmonella}

Stool sample were inoculated in a non-selective broth, selenite F enrichment broth and incubated at $37 \stackrel{\circ}{\circ}$ for 24 hrs, the pre cultured stool sample were sub cultured on deoxycholate citrate agar (DCA), salmonella shigella agar (SSA) agar and brilliant green agar (BGA) and incubated at $37^{\circ} \mathrm{C}$ for $18-24$ hrs where growth was detected based on their, colonial characteristic and morphological appearance on these media.

Blood samples were inoculated into Terathionate broth. A minimum of blood to broth ratio of 1 in $10 \mathrm{mls}$, was maintained, and this was incubated at $37^{\circ} \mathrm{o}$ and checked for signs of bacterial growth daily for up to seven days. Bottles that show signs of growth were subculture on to Brilliant Green Agar (BGA) Salmonella Shegela Agar (SSA), and Mac conkey Agar.

Blood culture broth with no bacterial growth after seven days was sub-cultured before being reported as negative result. Typical colonies of Salmonella appear as pink colonies with or without black centers. Many cultures of Salmonella produce colonies with large, glossy black centers or may appear as almost completely black colonies. [21]. 


\subsection{Biochemical screening and serology}

A range of biochemical test were used to confirm the suspected colonies on the selective agar,s these are Triple sugar iron agar (TSI), Urease, Indole and Simmon Citrate test [21].

Colonies considered to be salmonella ssp were further tested for somatic $(\mathrm{O})$ and flagella $(\mathrm{H})$ antigens polyvalent antisera (oxoid) [.5]

Table 1 Biochemical and Serology test of Salmonella (carried out)

\begin{tabular}{|c|c|c|c|c|}
\hline $\mathbf{S} / \mathbf{N}$ & Test Substrate & Positive & Negative & Salmonella \\
\hline 1 & TS I (glucose) & Yellow Bult & Red bult & + \\
\hline 2 & H2S (TS I lysine decarboxylase) & Blackening & No blackening & + \\
\hline 3 & Urease & Purple colour & No colour change & + \\
\hline 4 & Indole test & Violet colour at the surface & Yellow colour at the surface & - \\
\hline 5 & Simmons citrate & Growth blue colour & No growth, No blue colour & V \\
\hline 6 & Polyvalent flagellate test & Agglutination & No agglutination & + \\
\hline 7 & Polyvalent somatic test & Agglutination & No agglutination & + \\
\hline
\end{tabular}

\subsubsection{Antibacterial Sensitivity of Orthodox Drug for Typhoid Treatment}

The susceptibility testing was carried out by disc diffusion method using Mueller Hinton agar and it was tested in vitro for susceptibility to the following antibiotics (OXOID Ltd.,UK) suggested by WHO, 2010, Ciprofloxacin (CPX,10 $\mu \mathrm{g}$ ), Amoxicillin (AMC,30 $\mu \mathrm{g})$ and Cloramphenicol (CH,30 $\mu \mathrm{g})$ [22].

\subsubsection{Plant Sample Preparation}

The leaves and grass were washed, drained and air dried at room temperature and grounded to powder using mortar and pestle. All the powdered samples were labeled and stored in a dark polythene bags at room temperature prior utilization.

\subsubsection{Extraction Procedure of Plants Sample Prepared}

100 grams of each powder plant sample stored were weighed and extracted with methanol and aqueous (Water) for 36hours using soxhlet extractor [3]. This was done by wrapping the powdered plant material in filter paper and tucked in to the soxhlet tube and the solvent in the soxhlet flask. The set was then placed on a hating mantle under electric current and allowed to run for the above mentioned hours until extraction is complete by comparing colour difference of the tube (plant material) with that of the flask (extracts).

\subsubsection{Preparation of Inoculum}

Macfarland standard; 0.5 macfarland standard was prepared by $0.5 \mathrm{ml}$ of $1 \%$ Barium chloride $\left(\mathrm{BaCl}_{2}\right)$ to $99.5 \mathrm{mls}$ of $1 \%$ Sulphurics acid $\left(\mathrm{H}_{2} \mathrm{SO}_{4}\right)$. The turbidity of 0.5 macfarland stands was used for the estimation of the amount of salmonella. Colonies of Salmonella was suspended in sterilized $0.9 \%$ sodium chloride solution (normal saline) which was compared with 0.5 macfarland solution the microbial suspension $(1 \mathrm{ml})$ in normal saline was added to $74 \mathrm{mls}$ of sterile medium kept at $45^{\circ} \mathrm{C}$ to give bacterial population density of $1.2 \times 10^{7} \mathrm{Cells} / \mathrm{ml}$ [14].

\subsubsection{Preparation of Stock Suspension of Extract}

Stock preparation of plant extract was prepared by dissolving 0.4 grams of extract in to $1 \mathrm{ml}$ of dymethyl sulfoxide (DMSO) for methanolic extracts and $1 \mathrm{ml}$ sterilized distilled water was used for aqueous extracts to make $400 \mathrm{mg} / \mathrm{ml}$ and stored at room temperature pending usage.

\subsubsection{Assays for Antibacterial Activity of Plant Extracts}

The antibacterial activity was carried out by well diffusion method [6] . Preparation of inoculums was obtained using Macfarland standered to have inoculums density of $1.2 \times 10^{7} \mathrm{Cfu} / \mathrm{mls}$, wells of $4 \mathrm{~mm}$ in diameter were bored on already inoculated Muellar Hilton agar plates using a sterile well borer and $60 \mu \mathrm{L}$ of extracts was dispensed in the wells and 
stand for $40 \mathrm{~min}$. as pre-diffusion time, these were incubated at $37^{\circ} \mathrm{C}$ for $18-24 \mathrm{hr}$. Diameters of zones of inhibition was determined by subtracting the diameter of the wells and recorded to the nearest millimeter.

Preliminary testing of this preparation was carried out using the stock concentration $400 \mathrm{mg} / \mathrm{ml}$ to test whether or not the plant is active. The antibacterial activity assay was done in duplicate at concentrations 400, 200, 100 50 and $25 \mathrm{mg} / \mathrm{ml}$ were the means were taken as the mean zones of inhibition (MZI).

To investigate the synergistic activity of the extracts equal volume of $0.5 \mathrm{ml}$ from the stock preparation of both solvents, this combination was made in twos and the three and diluted to make concentration of 400, 200, 100, 50 and $25 \mathrm{mg} / \mathrm{ml}$.

\subsubsection{Determination of the Susceptibility of the Isolates to Some commonly used Antibiotics}

Susceptibility pattern of some commonly used antibiotic was carried to compare with that of the extract using disc diffusion method [22], Out of the commercially available disc drug of choice for typhoid were cut out, these are

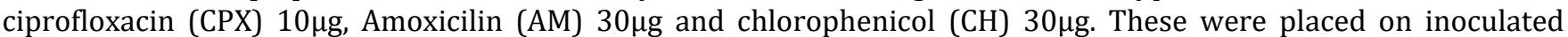
Mueller Hillton agar plates; zones inhibitions were measured after $24 \mathrm{hrs}$ incubation at $37^{\circ} \mathrm{C}$. This was carried out in duplicates and then the mean zone of inhibitions was used to calculate the activity index (AI) = The mean zones of inhibition for the crude extracts test divided by the mean inhibition zones for the commercial antibiotics [1].

\subsection{Phytochemical Analysis of Extract}

Phytochemical screening of methanol and aquoeus (water) extracts of Cymbopogan ciratus, Anacadium occdentale and Psidium guajava was done using standard procedure to determine the bioactive agents in the extract $[7,16,19]$.

\subsubsection{Test for Alkaloids: Dragendoff's Test}

$0.5 \mathrm{~g}$ portion of the leaves powder was stired in $5 \mathrm{ml}$ of $1 \%$ aq. $\mathrm{HCl}$ on a steam bath for about 5 minutes. The mixture was Filter through a Whatman No. 1 filter paper. 2-4drops of Dragendoff's reagent was added to $1 \mathrm{ml}$ of the filtrate. A change to orange colour indicates the presence of alkaloids. Being alkaline, alkaloids are readily extracted by mildly acidic aqueous solvents like $1 \%$ aq. $\mathrm{HCl}$. The test is valid only if the plant material is not colored.

\subsubsection{Wagner's Test}

To the $1 \mathrm{ml}$ o extract, add $2 \mathrm{ml}$ of Wagner's reagent. Reddish brown colored precipitate indicates the presence of alkaloids.

\subsubsection{Test for Saponins}

To abot $5 \mathrm{ml}$ distilled water in a test tube, $0.5 \mathrm{~g}$ of plant extract was added, shaken vigorously and observed, for frothing (small bubbles), the mixture was warmed by standing in a water bath (50 0C) for 10 minutes. Persistence of frothing on warming is an indication of the presence of saponins.

\subsubsection{Test for Tannins}

To $10 \mathrm{ml}$ distilled water in a test tube, $5 \mathrm{~g}$ of the plant extract was added Stired and then filtered through a Whatman No. 1 filter paper. $2-3 \mathrm{ml}$ of ferric chloride solution was added gradually to the filtrate. A deep green color (olive-green) indicates the presence of tannins.

\subsubsection{Test for Flavonoids}

$0.5 \mathrm{~g}$ portion of the extracts was added to $2 \mathrm{ml}$ dilute $\mathrm{NaOH}$ solution in a test tube and Shaken to dissolve. Then few drops of conc. $\mathrm{H}_{2} \mathrm{SO}_{4}$ were added. A colorless solution is an indication of flavonoids.

\subsubsection{Test for Anthraquinones}

To $10 \mathrm{ml}$ dilute $\mathrm{H}_{2} \mathrm{SO}_{4}$ in test tube $5 \mathrm{~g}$ of extracts was added and Boiled for a few minutes. Then filtered through Whatman No. 1 filter paper while the mixture is still hot. $5 \mathrm{ml}$ of ether was added to the filtrate and shaken to mix. It was allowing standing until the ether and aqueous layers separate out, then, $2.5 \mathrm{ml}$ of $10 \%$ ammonia solution was added. A pink or red or violet color in the aqueous layer indicates the presence of anthraquinones. 


\subsubsection{Test for Steroids}

To $1 \mathrm{mg}$ of the extract in a test tube, $5 \mathrm{ml}$ chloroform added. Then, equal volume of conc. $\mathrm{H}_{2} \mathrm{SO}_{4}$ was added by sides. The turning of red in the upper layer and yellow with green fluorescence in the sulphuric acid layer indicates the presence of steroids.

\subsubsection{Test for Glycosides (most classes)}

To $10 \mathrm{ml}$ boiling distilled $5 \mathrm{~g}$ of the extracts was added. Stirred and then filtered through Whatman No. 1 filter paper. A few drops of conc. HCL were added to $2 \mathrm{ml}$ portion of the filtrate. Boil for a few minutes to hydrolyze any glycosides present, a few drops of aqueous ammonia solution was added to make the mixture alkaline. Then five drops of the mixture to $2 \mathrm{ml}$ of Benedict's reagent was added and boiled. A reddish brown precipitate indicates the presence of glycosides.

\subsubsection{Test for Phlobatannins}

Few drops of $1 \% \mathrm{HCl}$ was added to $1 \mathrm{ml}$ of extract and boiled. A reddish precipitate indicates the presence of phlobatannins.

\subsubsection{Test for Terpenoids}

$2 \mathrm{ml}$ of chloroform was added to $0.5 \mathrm{~g}$ of the plant extract; follow by adding $3 \mathrm{ml} \mathrm{H} 2 \mathrm{SO}$. Reddish brown coloration at the interface which indicates the presence of terpenoids.

\subsubsection{Test for Resins}

To $2 \mathrm{ml}$ of extract plus equal volume of acetic anhydride solution was added and then drops of conc. H2SO4. Formation of colophony resins (violet coloration) indicates the presence of resins.

\subsection{Determination of Activity Index of the Plant Extracts}

Activity index was used to compare the inhibitory effect of the extract with that of the commercially available antibiotics. This was calculated as the mean zones of inhibition for the test extract divided by the mean inhibition zones for the commercial antibiotics [1,2].

\section{Results and discussion}

\subsection{Physical Properties of Plant Extracts}

Some of the physical characteristics of plant extracts such a colour texture and their dry weight are presented on Table 2. The plant part used are the leaf or green part of the plants. The initial weight of the powdered plant material was 100grams prior extraction, after the extraction, the colour of extract appeared green with methanol and brawn to dark brawn with aqueous. The of consistency varied, methanol extract of Anacadium occidentale was sticky and oilly with dry weight $37.5 \mathrm{~g}$, Psidium guajava was also sticky with dry weight 26.82 and Cymbopogan citratus was creamy and soft to touch with dry weight 17.78g. The aqueous extracts have these varying properties Anacadium occidentale gummy and oily with dry weight $16.17 \mathrm{~g}$.

Table 2 Physical Properties of Aqueous and Methanol Extracts of Plants

\begin{tabular}{|c|c|c|c|c|c|}
\hline Plant Species & Part & Colour & Name of consistency & $\begin{array}{l}\text { Initial weight in } \\
\text { (grams) }\end{array}$ & $\begin{array}{l}\text { Dry weight in } \\
\text { (grams) }\end{array}$ \\
\hline \multicolumn{6}{|l|}{ Methanol Extract } \\
\hline Anacadium occidentale & leaf & green & Sticky/Oily & 100 & 37.5 \\
\hline Psidium guajava & leaf & green & Sticky & 100 & 26.82 \\
\hline Cymbopogan citratus & grass & green & Creamy/soft on touch & 100 & 17.78 \\
\hline \multicolumn{6}{|l|}{ Aqueous Extract } \\
\hline Anacadium occidentale & leaf & Dark brown & Gummy/Oily & 100 & 16.17 \\
\hline Psidium guajava & leaf & brown & Flakes & 100 & 8.14 \\
\hline Cymbopogan citratus & grass & brown & Gummy & 100 & 20.94 \\
\hline
\end{tabular}




\subsection{Antibacterial Activity of Orthodox Antibiotics}

The effect of most used orthodox antibiotics for the treatment of typhoid fever was used as standards. Ciprofloxacin $(10 \mu \mathrm{g})$, Amoxacilin $(30 \mu \mathrm{g})$ and chromplanicol $(30 \mu \mathrm{g})$ were tested on typhoidal and non typhoidal Salmonella isolates to compare their activities of various plant extracts against the isolates. This is as presented on Table 3 . Chloramphencol have a significant zone of inhibition on the three Salmonella serotypes at various levels. While ciprofloxacin $(10 \mu \mathrm{g})$ exhibited highest effect on S. paratyphi A with mean zone of inhibition $20.5 \mathrm{~mm}$ followed by $S$. typhimurium $11 \mathrm{~mm}$ and Amoxicilin $(30 \mu \mathrm{g})$ has highest activity on S. typhimurium with mean zone of inhibition $9 \mathrm{~mm}$.

Table 3 Sensitivity Tests of some Antibiotics Used for the Treatments of Typhoidal and Non Typhoidal Salmonellosis

\begin{tabular}{llll}
\hline & \multicolumn{3}{c}{ Mean Zone of inhibition in (mm) } \\
Antibiotics in ( $\mu$ g) & S. typhi & S. paratyphi & S. typhimirium \\
\hline Ciprofloxacin (CPX) 10 & 1 & 20.5 & 11 \\
Amoxacilin (AM) 30 & 2 & 3 & 9 \\
Chloramphenicol (CH) 30 & 11.5 & 19 & 15 \\
\hline
\end{tabular}

\subsection{The Phytochemical Screening of Plants Extracts}

Photochemical Screening of plant Cymbopogan citratus showed positive result for the ten compounds tested except for flavonoids with aqueous extract and plabotanins with methanol extract having negative results. Psidium Guajava showed positive result on the entire compound tested except for Resins with aqueous extract; Antraqunone and plabotanins of methanol extracts had negative results. Anacadium occidantale also showed positive result on all the compounds tested except for resins of aqueous extracts, antraqunones and plabotanins of methanol extract that gave negative results.

\subsection{Phytochemical Analysis}

The phytochemical present in the extracts of the three plants, Anacadium occidentale, Psidium guajava and Cymbopogan citratus with methanol and aqueous solvent shown on Table 3 revealed positive result for most of the of the bioactive compounds which may be the reason for the antibacterial activity as described by many researchers $[20,6]$. The bioactive compounds positive to the screening of both aqueous and methanolic extract were Alkaloids Saponins flavonoids steriods, glycosides and terpenoids with negative result on methanol extracts for Antraquinones and Phlabotanins also in aqueous extracts of Resins.

Table 4 Phyochemical Screening of plant extracts

\begin{tabular}{|c|c|c|c|c|c|c|}
\hline \multirow[b]{2}{*}{ Bioactive Compound } & \multicolumn{2}{|c|}{$\begin{array}{l}\text { Cymbopogan } \\
\text { citratus }\end{array}$} & \multicolumn{2}{|c|}{$\begin{array}{c}\text { Psidium } \\
\text { guajava }\end{array}$} & \multicolumn{2}{|c|}{$\begin{array}{c}\text { Anacadium } \\
\text { occidentale }\end{array}$} \\
\hline & $\mathbf{A E}$ & ME & $\mathbf{A E}$ & ME & $\mathbf{A E}$ & ME \\
\hline 1.Alkaloids & + & + & + & + & + & + \\
\hline 2. saponins & + & + & + & + & + & + \\
\hline 3. Tanis & + & + & + & + & + & + \\
\hline 4. Flavonoids & - & + & + & + & + & + \\
\hline 5.Antraqunones & + & + & + & - & + & - \\
\hline 6. Steroids & + & + & + & + & + & + \\
\hline 7. glycosides & + & + & + & + & + & + \\
\hline 8.plabotanins & + & - & + & - & + & - \\
\hline 9. Terpenoids & + & + & + & + & + & + \\
\hline 10.Resins & + & + & - & + & - & + \\
\hline
\end{tabular}

Bioactive compounds are known to possess antimicrobial properties [1]. Tennins have been found to form irreversible complexes with protein - rich compounds resulting in inhibition of cell protein synthesis. This is an important effect 
for the treatment of inflamed or ulcerated tissue, [2] and can be used in ulcerated surfaces frequently experience by typhoid patient especially in perforated intestines and arthritis among the frequently occurring complication [18] while Tanins act by Coagulating the cell wall protein synthesis, Saponins are surface active agents which alter the permeability of the cells thus facilitates the flow of toxic materials or leakages of vital cell constituents, flavonoids being plenolic in nature are cytoplasmic poisons, inhibiting the activity of enzyme [19] which are of benefit to the pathogenesis caused by Salmonella organism Tannins containing herbs are astringent in nature and are used for astringents intestinal disorders such as dysentery and diarrhea [13] which is a major sign and symptoms of typhoid and non-typhoid Samonellosis.

\subsection{Analysis of the Activity Indices of Extracts Using Standard Antibiotics}

The activity index of extracts with the standard antibiotics is presented on Table 5.

Table 5 Activity Indices (A1) of Plant Extract at Concentration (400mg/ml) in Comparison with Antibiotics use for Treating Typhoid Fever

\begin{tabular}{|c|c|c|c|c|c|}
\hline Antibiotics & Plant & Organism & $\begin{array}{l}\text { MZI of } \\
\text { ntibiotics }\end{array}$ & Methanol & Aqueous \\
\hline \multirow{9}{*}{$\begin{array}{l}\text { Ciprofloxacin }(10 \mu \mathrm{g} \\
\text { /disc) }\end{array}$} & \multirow{3}{*}{$\begin{array}{l}\text { Cymbopogan } \\
\text { citratus }\end{array}$} & S. typhi & 1 & 9 & 11 \\
\hline & & S. paratyphi A & 20.5 & 0.24 & 0.32 \\
\hline & & S. Tyhimurium & 11 & 1.27 & 1 \\
\hline & Psidium & S. typhi & 1 & 17 & 16 \\
\hline & \multirow[t]{2}{*}{ guajava } & S. paratyphi $A$ & 20.5 & 0.82 & 0.90 \\
\hline & & S. Tyhimurium & 11 & 1 & 1.27 \\
\hline & Anacadium & S. typhi & 1 & 19 & 13 \\
\hline & \multirow[t]{2}{*}{ Occidentale } & S. paratyphi $A$ & 20.5 & 0.95 & 0.82 \\
\hline & & S. typhimurium & 11 & 1.54 & 1.54 \\
\hline \multirow{9}{*}{$\begin{array}{l}\text { Amoxacilin } \\
\mu \mathrm{g} / \text { disc })\end{array}$} & \multirow{3}{*}{$\begin{array}{l}\text { Cymbopogan } \\
\text { citratus }\end{array}$} & S. typhi & 2 & 4.5 & 5.5 \\
\hline & & S. paratyphi A & 3 & 1.66 & 2.16 \\
\hline & & S. typhimurium & 9 & 1.55 & 1.22 \\
\hline & Psidium & S. typhi & 2 & 8.5 & 8 \\
\hline & \multirow[t]{2}{*}{ guajava } & S. paratyphi $A$ & 3 & 5.66 & 6.16 \\
\hline & & S. typhimurium & 9 & 1.22 & 1.55 \\
\hline & Anacadium & S. typhi & 2 & 9.5 & 6.5 \\
\hline & \multirow[t]{2}{*}{ Occidentale } & S. paratyphi A & 3 & 6.5 & 5.66 \\
\hline & & S. typhimurium & 9 & 1.88 & 1.88 \\
\hline \multirow{9}{*}{$\begin{array}{l}\text { Chloramphenicol ( } 30 \\
\mu \mathrm{g} / \text { disc) }\end{array}$} & \multirow{3}{*}{$\begin{array}{l}\text { Cymbopogan } \\
\text { citratus }\end{array}$} & S. typhi & 11.5 & 0.78 & 0.95 \\
\hline & & S. paratyphi A & 19 & 0.45 & 0.34 \\
\hline & & S. typhimurium & 15 & 0.93 & 0.73 \\
\hline & Psidium & S. typhi & 11.5 & 1.47 & 1.39 \\
\hline & \multirow[t]{2}{*}{ guajava } & S. paratyphi A. & 19 & 0.89 & 0.97 \\
\hline & & S. typhimurium & 15 & 0.73 & 0.93 \\
\hline & Anacadium & S. typhi & 11.5 & 1.65 & 1.13 \\
\hline & \multirow[t]{2}{*}{ Occidentale } & S. paratyphi A & 19 & 1,02 & 0.89 \\
\hline & & S. typhimurium & 15 & 1.13 & 1.13 \\
\hline
\end{tabular}

Key: MZI = Mean Zone of Inhibition

Using ciprofloxacin $(10 \mu \mathrm{g})$ as standard, the indices of all the extracts were less than unity (AI $<\mathrm{I})$ on $S$. paratyphi A. with both methanolic and aqueous extracts followed by $S$. typhimurium which is slightly greater than unity (AI $>$ I) with

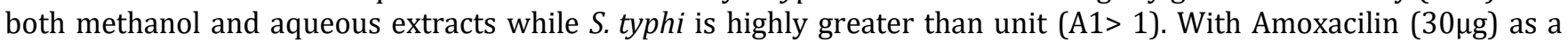
standard all extracts had indices greater than unity $(\mathrm{AI}>\mathrm{I})$ on all the three salmonella serotypes. Using 
chloramphenicol $(30 \mu \mathrm{g})$ as a standard S. paratyphi $A$ showed index less than or equal to unity (AI $\leq$ I) while $S$. typhi showed less than unity $(\mathrm{AI}<\mathrm{I})$ with cymbopogan citratus extracts indices was greater than unity (AI $>\mathrm{I})$ with anacadium occidentale and psidium guajava extracts $S$. typhimurium has indices less than unity $(\mathrm{AI}<\mathrm{I})$ with cymbopogan citratus and psidium guajava extracts indices was greater than unity $(\mathrm{AI}<\mathrm{I})$ with anacadium occidentale extracts indices was at unity $(\mathrm{A}=\mathrm{I})$.

\subsection{Comparison of the Activity of the Plant Extracts with the Orthodox Antibiotics}

The result of the investigation indicates that the extracts when compared with the standard antibiotics shoed significant activity. The high activity indices above unity value in the crude forms of extracts is an indication of more promising therapeutic advantage than the likes of Amoxacilin and ciprofoloxacin when refined to produce antibiotics especially in typhoid infection with serotype Salmonella typhi, the indication is that the extracts generally have a higher activity than the commercial antibiotics as a single crude drug with respect to $S$. typhi which had activity indices, above unity in comparison with the above mentioned antibiotics.

\section{Conclusion}

Extract showed significant in vitro activity as compared with the antibacterial activities of orthodox antibiotics, hence the pharmacological bases of use of these plants for treatment of typhoid fever. A base line data has been generated with respect to activity indices of these plants. The finding proved that chloramphenicol is still of value in the treatment of typhoid fever. Confirmed earlier results of other independent studies about activity of plants tested against the pathogen as promising. Plants prepared as drink can be packed into tea bags and used for treatment of typhoid and non-typhoid fevers.

\section{Recommendation}

Purification of photychemical compounds should be carried out to remove impurities and to identify the active compounds in the various plants. Pure compounds should be compared with the current antimicrobial agents or compounded together to yield better drugs and also take care of the problem of drug resistance that is presently becoming a problem globally.

\section{Compliance with ethical standards}

\section{Acknowledgments}

Our profound and immense appreciation goes to God Almighty who brought us thus far, to Him be all the glory, honour and adoration. Our appreciation goes to Head of Biological science department ATBU, Dr. A.B Samaila and the entire staff of the department, who gave us their moral and academic support and also made many useful suggestions. We also want to acknowledge Musa Muktari, Saidu Abubakar and Abdullahi Yahaya Mohammed of Biochemistry and Microbiology Department Gombe State University, for the permission to use their laboratory and also helped us in plant extraction and phytochemical screening. We gratefully acknowledge the constructive inputs, support and encouragement from colleagues, family and friends throughout the period of this research.

\section{Disclosure of conflict of interest}

The authors whose names are mentioned above declare that they have no conflict of interest as far as this publication is concerned, and should there be any conflict that may arise, it can be resolved amicably. The research is solely sponsored by the corresponding author.

\section{Statement of ethical approval}

In compliance with the ethical standard the consent of the clinically suspected patients was sort, while the Ethics Committee of Abubakar Tafawa Balewa University teaching Hospital Bauchi gave approval for the research. Confidentiality of the subjects' identities was duly maintained.

\section{References}

[1] Adegoke A and Adebayo-Tayo BC. (2009). Antibacterial Activity and pytochemical Analysis of leaf extract of Lasienthera africanum African journal of Biotechnology, 8(0), 077-080. 
[2] Awa Elizabeth Ihekerenma. (2011). photochemical screening and antimicrobial assay of some Nigerian medicinal plants Against Opportunistic pathogens in HIV/Aids patients. Unpublished M. microbiology thesis, 12-13.

[3] Benson HJ Microbiological Application 8th Edition New York Mc Graw Hill 2002 fig 21-1, 87.

[4] CDC-Centre for Disease Control and Prevention. (2008). Multistate outbreaks of salmonella typhimurium infections linked to peanut butter 2008-2009 (final update).

[5] Cheesbrough M. (2006). Salmonella species. In District Laboratory Practice in Tropical Countries. Low-priced ed. Cambridge, 182-186.

[6] Chukwura EI and Iheukwumere IA. (2012) Determination of Synergistic effect and activity index of Solenostemon monstachyus and ocimum gratissimum on selected bacteria. Nigeria, Journal of microbiology, 26, 2492 - 2497.

[7] Culer I. (1982). Methodology for the analysis of vegetable drugs.

[8] Guyton and Hall. (2000). Text book of Medical Physiology 12th edition.

[9] Jawetz Melnick and Adelberg Medical microbiology. (2013). 26th edition, 238-239

[10] Odugbemi T. (2006). Outline of medicinal plant in Nigeria 1st Edition, University of Lagos press Nigeria, 77.

[11] Ogundare A0. (2011). Antibacterial properties of leaf extracts of vernoia anygdalina, Ocinum gratissi, Corchorous Olitorious and Manihot palmate. Nigerian Journal of Microbiology, 25, 2269-2279.

[12] Oyetayo VO. (2009). free radical scavenging and antimicrobial properties of extracts of wild mushrooms Brazilian journal of microbiology 40, 380-386.

[13] Pharmanda S. (2003). Gallnuts and uses of Tannius in Chanese Medicine - A paper delivered at Institute for Traditional Medicine Portland, Orogan.

[14] Runyoro KB, Deborah M, Olipa D, Cosam CD and Zakaria HM. (2016) screeming of Tanzian Medicinal plants for anticandidial activity Bank Complementary and Alternature Medicine 6.

[15] Slayer AA and whiff DO. (1994). Bacteria pathogens 1st edition AMS press Washington DC, 120 -204.

[16] Sofowara A. (1993). Medicinal Plants and Traditional Medicine in Africa.

[17] Sofowara A. (1999). Medical plants and traditional medicine in Africa 3rd edition spectrum books limited Ibadan, 172 - 108.

[18] Thompson GR, Petal P, West book SD, Berg D, Erlanse J, Redding SW and Peterson TF. (2009). Pharyngeal candiasis in the era of antiretroviral therapy. Oral surgery, oral medicine, oral apthology, oral radiology and endontology, 109 (4), $488-495$.

[19] Trease GE and Evans WC. (2002). Pharmacognosy. 15th Edn. Saunders, 214-393.

[20] Umamasheswari A Shree Vidya R and Aparna N. (2008) in Vitro antibacterial activity of Bouganuillea spectabilis leaves extract Adu Bio Res, 2, 1-5.

[21] United States Department of Agriculture food safety and inspection service (USDFSIS) Salmonella question and answers USDA FSIS. (1998).

[22] WHO. (2010). Laboratory protocol susceptibility testing of enterobacteriacae using disk diffusion WHO Global food borne infection Network.

\section{How to cite this article}

Naphtali E, Tahir F and Agbo EB. (2020). Evaluation of phytochemicals and activity index of some plant leaf extracts on typhoidal and non-typhoidal Salmonella Isolates from selected hospitals in Bauchi, Nigeria Biological and Pharmaceutical Sciences, 10(2), 120-129. 